\title{
TEacher-ToOl Relationship of Maldivian EsL Teachers: A Multiple Case Study
}

\author{
Aishath Wadheefa ${ }^{a}$ \\ Meng Yew Tee \\ University of Malaya
}

\begin{abstract}
A major curriculum reform was implemented in Maldives in 2015. Little is known about how the new curriculum has been used and implemented in classroom teaching. This qualitative multiple-case study aims to examine the teacher-tool relationship of six teachers teaching sixth grade English and the factors that shape the teacher-tool relationship. The teachers were situated in four schools with distinct contexts - a densely populated urban context, a sparsely populated island with multi-grade classrooms, an island dependent on fishing and an island dependent on tourism. Data collected include three video-recorded observations of each teacher as well as post and pre-observation interviews. Brown's Design Capacity for Enactment Framework (DCEF) was used as a basis to see whether teachers offload, adapt or improvise the curriculum. In addition, an analysis of the descriptive data, across and within the cases was done to identify factors that shape the way teachers use the curriculum. The analysis revealed that teachers use the curriculum in distinctive ways and included multiple layers of offloading, adapting, improvising and omitting. The way teachers use the curriculum varies from one teacher to another, from one lesson to another, and from one activity to another. Curriculum tool features, individual characteristics as well as the island context played significant roles in shaping how teachers use the curriculum in their teaching. The results of the study can provide curriculum developers with a different perspective in designing curriculum tools, particularly to create flexible affordances within the curriculum to allow for differing teacher and locational characteristics.
\end{abstract}

Keywords: curriculum use, teacher-tool relationship, curriculum tools, curriculum

\section{Introduction}

Maldives is an archipelago of 1200 coral islands grouped in a double chain of 26 atolls about a thousand kilometres southwest of the Indian subcontinent. The 200 inhabited islands have a population of 338,434 people (National Bureau of Statistics (NBS), 2015). Four of these islands have a population of more than 5000 people and 72 islands have fewer than 500 inhabitants (NBS, 2015).

While Maldives has succeeded in providing greater access to education, calls to improve the education system in Maldives have increased over the years. Aturupane and Shojo (2012) stated that "evidences from varieties of sources show that education quality in the Maldives is weak and needs urgent improvement" (p. 1). The low average scores from the national assessment suggest that the primary and secondary education is weak and unsatisfactory (Shiuna \& Sadig, 2013). Moreover, students who graduate from schools seemed to lack the skills and competency expected by employers as well as higher education institutions. Mounting pressure to improve the quality of education in Maldives, combined with the needs of nation-building, led to major curriculum reform in 2015. New policies to guide assessment and inclusive practices came alongside the new curriculum. The age-level grades were changed to key stages. New subjects as well as new curriculum tools, such as

a Correspondence can be directed to: a_wadhyfa1993@hotmail.com 
syllabi, textbooks and teachers' references, were introduced. However, little is known about how the new curriculum tools are used and implemented by the teachers in their classroom teaching.

Yan (2012) argued that the success of curricular reform is unpredictable as teachers engage in a complex relationship in implementing the curriculum in real practice. Brown (2009) illustrates the complex relationship between teachers and the curriculum tools by using a jazz metaphor. The same song written as sheet music can be performed in significantly different ways by different jazz musicians. Sometimes the distinction can be so great that listeners have difficulty in recognizing that it is the same song. Brown argued that curriculum and sheet music are similar in that both eventually manifest in "live performances" which "heavily rely on the interpretation" of the users (Brown, 2009, p. 21). In both situations, the competency of the users - the musicians or the teachers - contributes to the eventual quality of the performance (Brown, 2009). In this regard, when the new curriculum is enacted in Maldives' classroom, the teachers may use the curriculum in various ways, leading to different instructional outcomes. Brown (2009) observed that the features of the curriculum and the teachers may contribute to shape the differences in the instructional outcomes of the teachers.

In framing this study, the unique characteristics of Maldives as a small atoll-nation were taken into account. Since Maldives is made up of small isolated islands, the distinctive features of island life may also shape the interaction between the curriculum and the teacher (Di Biase, 2015). Seeing through the lens of islandness (Lisle, 2012) and of small state theory (Crossley, 2010), one can begin to anticipate how a school situated in its self-contained socio-economic enclave can magnify the impact of how teachers interact with the curriculum. Hence, the specific aim of this study was to examine and describe how teachers used the newly introduced competency-based English curriculum in their teaching, in light of the context of the teacher and the school.

\section{Conceptual Framing of this Study}

Reviews of past research on curriculum use suggest four different perspectives in studying the relationship between teachers and the curriculum (Brown, 2009; Collopy, 2003; Freeman \& Porter, 1989; Remillard, 2005; Smith, 2000). One perspective is to view the written curriculum as something to be followed by the teacher (Freeman \& Porter, 1989: Synder et al, 1992). A key question often asked from this perspective is: is the teacher subverting or faithfully following the curriculum? This view - generally referred to as the fidelity perspective (Snyder et al, 1992) - assumes that the curriculum is fixed and the teacher is a conduit of the curriculum, with few other options to translate content to students (Remillard, 2005). Seeing teachers as a mere conduit not only limits creativity and responsiveness to different needs and contexts, but it also limits effective classroom instruction and student learning (McLaughlin, 1978; Remillard, 2005).

Another perspective focuses on curriculum use as drawing on the text (Remillard, 2005). In this perspective, curriculum materials are considered helpful tools for teachers but, unlike cultural tools or artefacts (Wertsch, 1991), they do not have the power to shape human activity. Conversely, Sosniak and Stodolsky (1993) have argued that teachers actually view curriculum materials as "props in the service of managing larger agendas" (p. 271). This gives rise to a third perspective - one that focuses on the larger agendas of curriculum use and the teacher-curriculum relationship. Through this lens, the teacher is viewed as the agent or interpreter of the text in the curriculum process (Lloyd, 2008; Ramillard, 2005), but the nature of the relationship is unilateral. A fourth perspective that emphasizes a more bilateral teacher-tool relationship emerged. This study draws upon this fourth perspective.

Central to this fourth perspective is the assumption that teachers and curriculum engage in a dynamic interrelationship that involves participation on the part of both the teacher and the tool, known in the relevant literature as a teacher-tool relationship (Brown \& Edelson, 2003; Remillard, 2005). This perspective allows for a closer examination of the relationship teachers forge with curriculum tools, and how teachers react to and use these tools, the factors that influence this reaction, and the effect that this relationship has on the teacher and on the implemented curriculum. 
The conceptual basis of this perspective comes from Vygotsky's notion of tool and mediation, which emphasized the use of tools as a sociocultural product in all human activities (Remillard, 2005). Artefacts as mediational means refer to products of social and historical development that people use to facilitate activities (Vygotsky, 1978). The key features of artefacts according to Vygotsky (1978) are that they assist people in achieving goals that otherwise might not be achieved and they mediate action in explicit ways. Wertsch (1991), for example, used the 'half-full' and 'half-empty' expression to emphasize the enabling or limiting potential of mediating artefacts. The half-empty view has the potential to constrain activities. In this study, the curriculum tools are regarded as cultural artefacts with the potential to enable, extend, or constrain what teachers do in classroom. The way the teacher interacts with the curriculum tool can place important enablers or constraints on the teacher's effort to help students learn.

Remillard and Bryan (2004), Sherin and Drake (2006), and Brown (2009), amongst others, have focused on this participatory approach in curriculum use to examine teachers' participation with the text. They have developed frameworks to characterise how teachers use the curriculum. In this regard, Sherin and Drake (2006) have suggested that teachers have specific ways of using curriculum tools at different phases of teaching, that is, prior to, during, and after the lesson. They categorise curriculum use in terms of reading, evaluating, and adapting. Remillard and Bryans (2004), on the other hand, developed three broad categories of curriculum use based on their analysis of the role that curriculum materials play. These are thorough piloting, adopting and adapting, and intermittent and narrow use. However, it was Brown's (2009) Design Capacity for Enactment Framework (DCEF in short, see Figure 1) that provided the initial grounding to frame this study.

The DCEF's conceptualization of teacher-tool relationship provided the initial lens to focus the inquiry, particularly concerning the way teachers use curriculum (i.e. offloading, adapting, and improvising), as well as the factors that shape this teacher-tool relationship. Teachers who offload from the curriculum rely significantly on the curriculum materials to support instruction, effectively shifting the curriculum design responsibility to the tools (Brown, 2009; Brown \& Edelson, 2003). On the other hand, teachers who adapt from the curriculum adopt certain elements of the curriculum design, but also contribute their own design elements to the implementation, effectively "sharing" the responsibility of curriculum design between themselves and the curriculum tools. Finally, teachers who improvise, based on the curriculum, pursue instructional paths of their own making. The curriculum tools may provide a 'seed' idea, but the teacher contributes the bulk of the design effort required to bring the activity to fruition. Figure 1 shows the Design Capacity for Enactment Framework originally developed by Brown (2009). The DCEF captures the elements of the teacher-tool relationship and shows the different types of interactions - offloading, adapting and improvising - that occur between teacher-resources and curriculum resources.

\section{Figure 1: The Design Capacity for Enactment Framework by Brown (2009)}

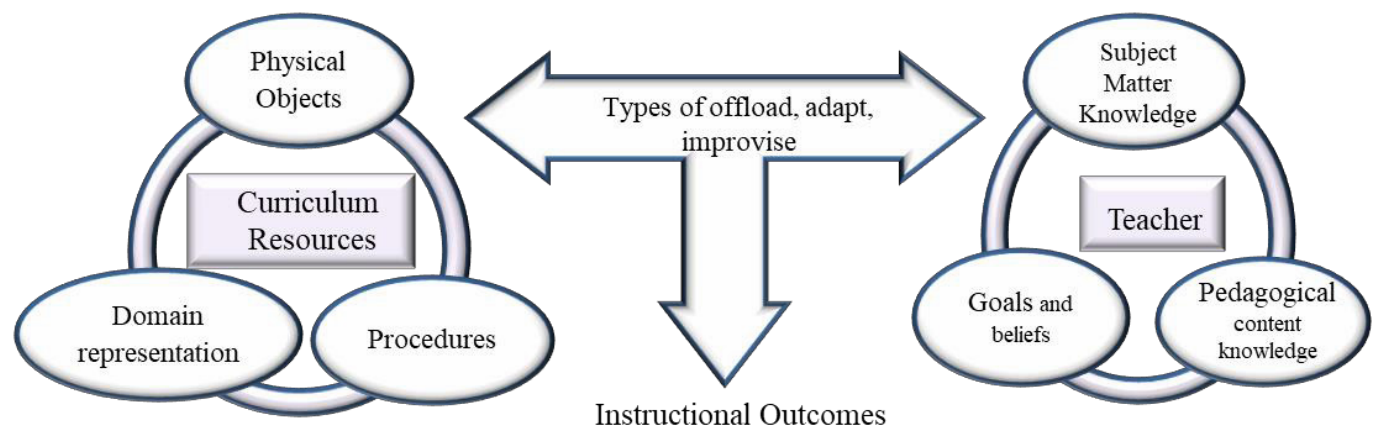

The DCEF provided an initial lens to examine and describe the teacher-tool relationship, and the concept of "islandness" allowed for deeper examination of how the unique features of the Maldives' landscape can shape the interaction between the teacher and the tool. 


\section{Research Methodology}

Adopting the teacher-tool relationship lens, this study aimed to describe Maldivian teachers' relationship with the new English curriculum and the factors that shape this relationship. The questions it sought to answer were:

1. What are the experiences of a selected sample group of teachers from the Maldives regarding the teacher-tool relationship in delivering the English curriculum?

2. What are the important influences identified by these teachers regarding their experiences of the teacher-tool relationship in delivering the English curriculum?

To address these research questions, a multiple-case study design, informed by an interpretivist paradigm (Merriam, 2009), was employed. This design allowed the researcher to gain an insight into the teachers' relationship with the curriculum in their respective settings, by contrasting and comparing the results within and across the cases.

The multiple-case design also permitted the research to focus on the four relatively distinct Maldivian island contexts that formed the basis for the sampling. Six teachers teaching Year 6 English in four schools situated in distinct contexts - three teachers from a densely populated urban context, one from a sparsely populated island with multi-grade classrooms, one from an island dependent on fishing income, and another from an island dependent on tourism income - agreed to be part of this study. A description of the four schools and the six teachers is presented in Tables 1 and 2. The six teachers gave their informed consent, after permission had been obtained from Ministry of Education (MOE) and the school principal. Measures such as assigning pseudonyms to each participant were used to maintain confidentiality and anonymity of the research participants.

To provide for trustworthiness (Merriam, 2009), member checking was done by sharing the interview transcripts with the participants. Triangulation of methods allowed for interviews to be checked against video-recorded observations and document analysis. Data for the study were collected from the participants over a period of four months, over multiple interviews and observations. In addition, thick description was employed when reporting the findings. During data collection and analysis, peer debriefing was done with a colleague of the first author, as well as with the second author.

Table 1: Description of the Selected Research Sites

\begin{tabular}{|c|c|c|c|c|}
\hline Schools & School A & School B & School C & School D \\
\hline $\begin{array}{l}\text { Characteristic of } \\
\text { context }\end{array}$ & $\begin{array}{l}\text { Urban, capital } \\
\text { city }\end{array}$ & $\begin{array}{l}\text { Situated on an } \\
\text { island dependent } \\
\text { on tourism. } \\
\text { Surrounded by } \\
\text { many resorts }\end{array}$ & $\begin{array}{l}\text { Situated on a } \\
\text { sparsely populated } \\
\text { island. Main } \\
\text { employer is the civil } \\
\text { service. } \\
\text { Subsistence fishing }\end{array}$ & $\begin{array}{l}\text { Situated on an } \\
\text { island highly } \\
\text { dependent on } \\
\text { fishing. Larger } \\
\text { scale fishing is } \\
\text { lucrative, and thus } \\
\text { an attractive career } \\
\text { pathway }\end{array}$ \\
\hline $\begin{array}{l}\text { Number of } \\
\text { students }\end{array}$ & $\begin{array}{l}1200 \text { Students } \\
\text { from } \\
\text { Grade } 1 \text { to } 12\end{array}$ & $\begin{array}{l}529 \text { students from } \\
\text { Grade } 1 \text { to } 10\end{array}$ & $\begin{array}{l}75 \text { students from } \\
\text { Grade } 1 \text { to } 10 \text { (multi- } \\
\text { grade classrooms) }\end{array}$ & $\begin{array}{l}337 \text { students from } \\
\text { Grade } 1 \text { to } 10\end{array}$ \\
\hline $\begin{array}{l}\text { Teacher population } \\
\text { and their academic } \\
\text { qualification }\end{array}$ & $\begin{array}{l}\text { Around } 90 \\
\text { teachers. All the } \\
\text { teachers have } \\
\text { a Bachelor's } \\
\text { degree and } \\
\text { above }\end{array}$ & $\begin{array}{l}\text { Total } 51 \text { teachers } \\
\text { (of which, } 15 \\
\text { teachers have } \\
\text { never done teacher } \\
\text { training) }\end{array}$ & $\begin{array}{l}\text { Total } 20 \text { teachers (of } \\
\text { which, } 10 \text { teachers } \\
\text { have never done } \\
\text { teacher training) }\end{array}$ & $\begin{array}{l}37 \text { teachers; all with } \\
\text { Bachelor's Degree } \\
\text { and above }\end{array}$ \\
\hline
\end{tabular}




\begin{tabular}{|c|c|c|c|c|}
\hline $\begin{array}{l}\text { The person who } \\
\text { monitors and } \\
\text { guide curriculum } \\
\text { implementation in } \\
\text { Grade } 6\end{array}$ & $\begin{array}{l}\text { A qualified } \\
\text { Leading } \\
\text { Teacher with } \\
\text { English teaching } \\
\text { background }\end{array}$ & $\begin{array}{l}\text { A Leading Teacher } \\
\text { not having } \\
\text { English teaching } \\
\text { background }\end{array}$ & $\begin{array}{l}\text { A Leading Teacher } \\
\text { who supervises all } \\
\text { the grades }\end{array}$ & $\begin{array}{l}\text { A Grade Leading } \\
\text { Teacher; responsible } \\
\text { to supervise all the } \\
\text { subjects in Grade } 6\end{array}$ \\
\hline Job opportunities & $\begin{array}{l}\text { Advanced } \\
\text { economy in } \\
\text { the urban area } \\
\text { provides a vast } \\
\text { number of } \\
\text { employment } \\
\text { opportunities } \\
\text { from various } \\
\text { fields }\end{array}$ & $\begin{array}{l}\text { The surrounding } \\
\text { tourist resorts } \\
\text { provide lots of job } \\
\text { opportunities }\end{array}$ & $\begin{array}{l}\text { Only a few jobs in } \\
\text { the government } \\
\text { offices }\end{array}$ & $\begin{array}{l}\text { Fishing industry } \\
\text { provides career } \\
\text { options with good } \\
\text { income }\end{array}$ \\
\hline
\end{tabular}

Table 2: Information of the Research Participants

\begin{tabular}{|c|c|c|c|}
\hline $\begin{array}{l}\text { Participant } \\
\text { (Pseudonyms) }\end{array}$ & Experience & Teaching context & Teaching qualification \\
\hline Ashia & 7 years & School A: Urban context & $\begin{array}{l}\text { Diploma in TESOL and Bachelor's } \\
\text { degree in Educational Management }\end{array}$ \\
\hline Becky & 17 years & School A: Urban context & Bachelor's Degree in English \\
\hline Kadhy & $\begin{array}{l}\text { Less than } \\
1 \text { year }\end{array}$ & School A: Urban context & Doing the final year in TESOL \\
\hline Daisy & 8 years & $\begin{array}{l}\text { School B: On an island } \\
\text { dependent on tourism }\end{array}$ & Master's degree in English \\
\hline Edmon & 24 years & $\begin{array}{l}\text { School C: On a rural, } \\
\text { sparsely populated island }\end{array}$ & Masters of Arts in English \\
\hline Faiha & 7 years & $\begin{array}{l}\text { School D: On an island } \\
\text { dependent on fishing }\end{array}$ & $\begin{array}{l}\text { Diploma in middle school teaching of } \\
\text { English and Social Studies, Bachelor's } \\
\text { degree in Primary Teaching }\end{array}$ \\
\hline
\end{tabular}

Each teacher was observed and video-recorded three times. The video data helped capture the lesson contents and the verbal interactions and events in detail (Tee, Samuel, Mohd Nor \& Nadarajan, 2016; Jacobs et al, 1999). Each observed lesson was accompanied with pre-observation and postobservation interviews. The pre-observation meetings were carried out to better understand the teacher's planned lesson activities and their rationale, and to determine the curriculum objectives and related segments the teacher was planning to implement.

The post-observation interviews enabled discussion about each teacher's intention and goals in using a particular curriculum implementation approach, lesson activities, exercises and interactions. It also helped the researcher to understand the reasons for their actions and to better understand the teachers' content knowledge and pedagogical knowledge, views and beliefs. In addition, the researcher also observed the subject coordination meetings. The discussions during these meetings 
gave insights into the teachers' plans in teaching particular topics, lessons and activities, as well as the ways they interacted with the curriculum.

Documents such as lesson plans, unit outlines, curriculum documents and meeting minutes were also collected. These permitted a better understanding of what was prescribed and intended in the curriculum.

The data were analysed - within-case and cross-case - initially through the lens of the DCEF model, but with open coding to allow a comprehensive range of themes to emerge from the data (Merriam, 1998). The within-case analysis provided for comparing and contrasting how teachers within the same school use curriculum tools in different lessons. Meanwhile, the cross-case analysis allowed for comparison of the teacher-tool relationship across the different teachers situated in different schools.

\section{Results}

Based on the analysis, a number of similarities and differences in the teacher-tool relationship were identified. A summary of the findings is presented in Figure 2, followed by a discussion of how teachers used the curriculum and the factors which shaped the teachers' behaviour. The Venn diagram in the centre of Figure 2 locates where each teacher was in terms of a relationship with the curriculum tools. One of the teachers, Kadhy, for example, faithfully offloaded from the curriculum. Another teacher, Edmon, had a greater tendency to omit, adapt or improvise. The items in the grey circle are teacher-related, tool-related or context-related features that shaped the teacher-tool relationship.

\section{Figure 2: The Teacher-tool Relationship and the Factors that Shape this Relationship}

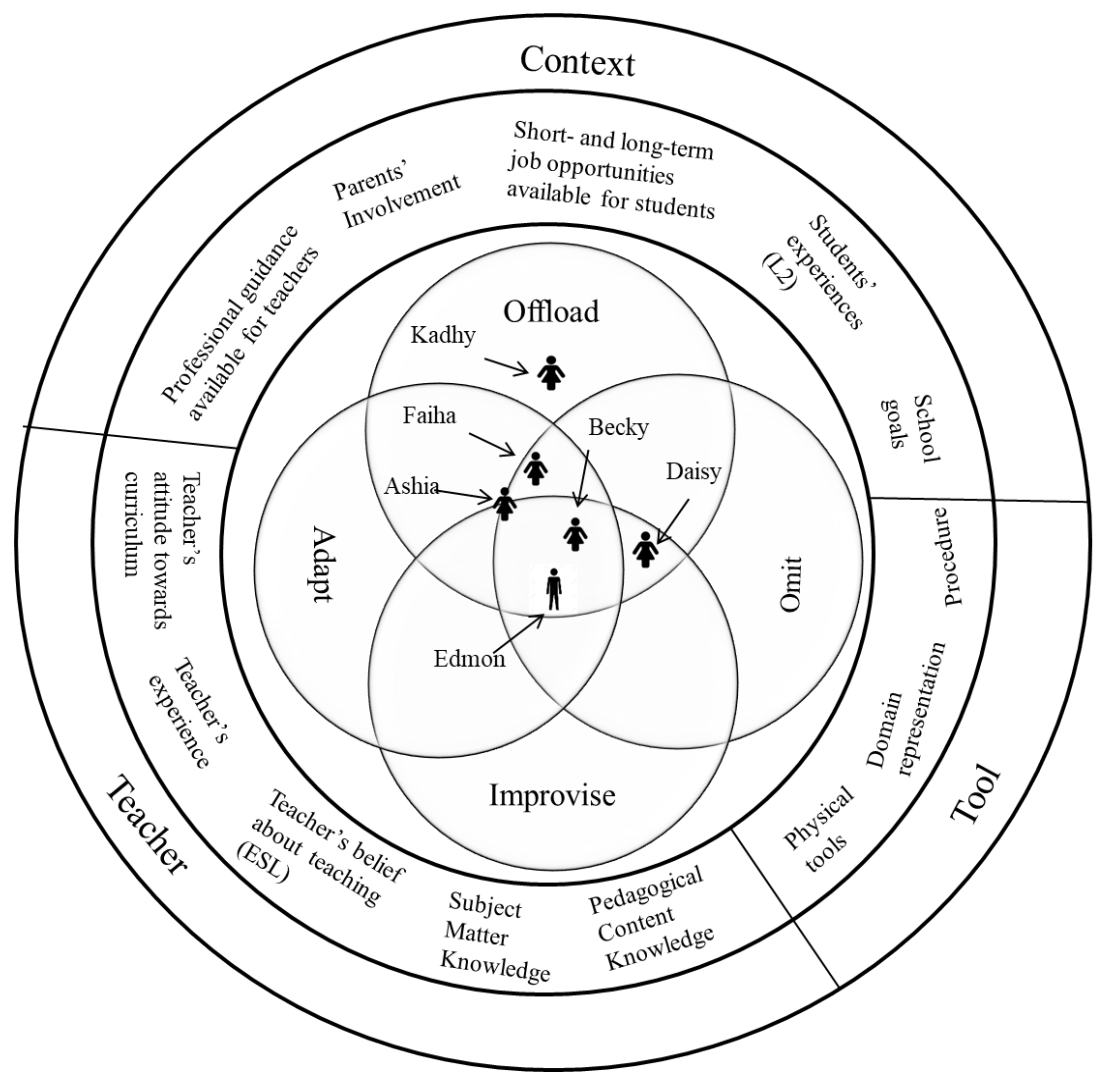




\section{Offloading}

The analysis of data revealed that all the teachers offloaded the tool to a certain extent. For example, all the teachers used the reading text and listening exercise as given in the textbook. However, Ashia, Kadhy and Faiha offloaded more than Edmon, Becky and Daisy, contributing very little of their own ideas to the curriculum implementation process. These three teachers followed almost all the tasks given in the tools, with little adaptation.

While Kadhy offloaded the most, Ashia and Faiha seemed to share a similar teacher-tool relationship. Kadhy, who has been teaching for nearly a year, depended significantly on the instruction and teaching resources prescribed in the tool without any change. She followed the curriculum faithfully - not adapting or improvising any of the tools, instructions or tasks. For example, in the lesson where students were supposed to make a leaflet, Kadhy gave exactly the same instruction and made students follow the same steps given in the student book, while other teachers adapted.

Much of the offloading behaviour of all the teachers was shaped by their positive attitude towards the new curriculum. The teachers seemed to recognize that the curriculum was improved to provide better teaching and learning opportunities for the students. Ashia, for example, explained that "the new curriculum is based on eight key competencies which are important and it clearly filled the inadequacy of the old curriculum." The teachers also highlighted that teaching had become more learner-centered, making students more responsible for their learning. As Faiha explained, "The old curriculum was very much teacher-centered and textbook-based but the new curriculum is student-centered and makes students more responsible for their learning."

All the participants agreed that the new curriculum supported teachers in their implementation of the new curriculum. The teachers viewed the curriculum resources as tools which must be used in their teaching. Talking about the suitability of these tools during the interview, the teachers explained that the new curriculum is very useful as MOE has designed, printed and disseminated all the learning materials needed to implement the new curriculum. Faiha, for example, said that "the good thing about the curriculum is, everything is provided. The textbook is based on the learning outcomes and, we are recommended to use the exercises in the textbook. Resource materials are also given in the teachers' guide."

However, it is important to highlight that some teachers, particularly Becky, Edmon and Daisy, had a different perspective about the tool. They viewed the tool as a guide to support their teaching, but not as exclusive resources which must be used in their teaching. The three teachers were educated and trained overseas, and their views seemed to be different from those of the other teachers. Daisy explained, "I understood that all subject texts are designed on the basis of syllabus. But the textbook alone is not satisfying as a tool to teach the present curriculum in the classroom. So, we need to use other interesting tools [depending on] the concentration of the students."

There were other significant forces that shaped how the tools were used. Faiha, from the school situated on an island dependent on large-scale fishing, said that the parents and school management emphasized using the textbook. Parents will complain if they find exercises which are left incomplete in the textbook. According to her, "the parents and the school management want something that they can actually 'see' to measure the 'learning'. There are 18 units in the new syllabus for grade 7. By the end of the last semester, I was [only] able to cover 9 units... so parents complained about it." On the other hand, Becky, Ashia and Kadhy from the urban school explained that their parents were very much aware of the new curriculum; hence they did not expect teachers to teach exactly what was given in the tools. Most of the parents wanted their children to have more diverse learning opportunities. This encouraged teachers to use other tools. Ashia explained that "Our parents know a lot about the new curriculum content, the teaching strategies and assessment methods due to the various parents' awareness programs conducted by the school. So they don't bother even if the textbook work is not completed." 


\section{Adaptation}

The teachers also adapted, contributing their own knowledge and skills. Edmon, Becky, Ashia and Faiha adapted some of the tools when they implemented them in their classrooms. They either modified the teaching resources, tasks or instruction given in the tool to make it more suitable for the learning needs of the students.

Out of the four teachers, Edmon, from the sparsely populated rural island, adapted the most. He modified almost all the tools proposed in the curriculum, with the intention of making it more suitable for his students. Becky and Ashia adapted less than Edmon did but adapted more than Faiha. Faiha felt pressure from the parents and school management to offload the tool and to complete the exercises in the books, so when she adapted, she mainly did so with the introductory task stated in the curriculum. Becky and Ashia from the urban school adapted the tool to provide more challenging tasks to their students.

Teachers who have spent more years in teaching adapted more when compared to the teachers who have spent less years in teaching. All the teachers agreed that the way they use the curriculum tools changed as they gained more experience in teaching. The four teachers who had been teaching for more than seven years stated that with more years of service they had become more aware of the language needs of the students in the different teaching context. So they adapted from the tool depending on the students. Ashia explained: "As I spend more years in teaching, I adapt and use my own styles and I use the textbook less than before."

The teachers' pedagogical content knowledge and subject content knowledge also shaped their adaptation behaviour. When teachers became more aware of the various teaching techniques and learning methods, they seemed to adapt the given tool to better suit the students' learning preferences and language needs. For example, Faiha explained why she had to change her plan: "I understood that it would be difficult to discuss based on their general knowledge. Even though we plan very interactive activities when we write the lesson plan, we cannot always carry out those activities in a real classroom. Very often, I have to change my plan after entering the classroom." Teachers in the rural schools, particularly Edmon and Daisy, had weaker content knowledge than the teachers in urban areas. As a result, they depended heavily on the brief explanation of the content in the tool, without providing further explanation to the students. Moreover, when the two teachers adapted and improvised they seemed to select the tools, concepts or tasks, which were more familiar to them and, which could be easily and comfortably implemented in the classroom.

Other important factors that shaped teachers' adaptation behaviour included the suitability of the content and procedures given in the curriculum. Very often teachers seemed to adapt from the tool, when the tasks and concepts given were too complex or too easy for students. Edmon, who taught in a rural community where very little English was spoken, modified most of the questions given in the tool because they were too difficult for his students. Edmon stated: "Some of the questions are very complicated. According to these students' standard, they can't do those questions. They find it difficult to do the questions. So I change them. But the questions are good for the students in well-developed islands." The students' language experiences at home and at school was different from those of students in the urban area, and the language proficiency seemed to be far weaker than the students in the urban school. Daisy expressed that: "the students do not watch TV or cartoon at home. They don't talk in English. So, they are weak in English." On the other hand, Becky and Ashia from the urban school had to adapt the tool to provide more challenging opportunities for the students, because having exposure to the language at home, their language competency was much better than the students in rural schools.

\section{Improvising}

With the exception of Kadhy, all the other five teachers improvised some of the tools as they implemented their lessons. Using the learning outcomes given in the curriculum as the "seed" idea, the teachers used materials created on their own or adapted from the internet, to deliver their 
lessons. In this regard, Edmon improvised the most, followed by Becky and Daisy. These teachers improvised three to four main activities in the three lessons observed, incorporating very little of what is prescribed in the tool. Ashia improvised occasionally, while Faiha improvised one activity.

One of the key factors shaping teachers' improvising behaviour was the exam-oriented education policy. All six teachers seemed to give particular importance to exam-oriented practices as they implemented their lessons. This behaviour is in large parts shaped by school rankings. Schools are ranked according to the result of an international exam administered the end of Year 10 and Year 12. Rural schools tend to be more poorly ranked than urban schools. As a result, teachers in the rural schools tend to put more emphasis on exam results. Daisy, who taught on a rural island dependent on tourism, was a typical example. She improvised from the tool to give students more exam-oriented exercises. She explained: "Our result was very low for the past few years. So I feel that it is important to do some exam-related lessons."

Another key factor in shaping the teachers' improvising behaviour was their belief about language teaching. Becky and Edmon's beliefs about language teaching, for example, were quite different from those of Ashia, Daisy and Faiha. Becky and Edmon were trained and educated in an era where grammar-translation and audio-lingual methods were given greater emphasis in teaching English. Hence, their teaching involved much more explicit teaching of vocabulary and grammar rules. These two teachers improvised the lesson to include grammar and vocabulary activities in their lessons because they believed that these aspects were crucial in learning a language. As the new curriculum promoted implicit grammar teaching, this improvisation could possibly affect curriculum implementation negatively.

When the two teachers were asked about their reasons for including aspects of grammar and vocabulary in their lessons, they explained that without grammar and vocabulary the students will not be able to learn the language.

As a teacher I have to develop students' fundamental knowledge in English. As primary level students, they must be trained with basic grammar and vocabulary to improve their listening, speaking, reading and writing. With that aim in mind, I gave more importance to the grammar and vocabulary. I understood that it is the base to every language learner.

A third key factor that shaped all the teachers' improvising behaviour was the extent of the students' short-term and long-term job opportunities. For example, although it was earlier assumed that students in this tourism-based region would need an English qualification to secure a job in the tourist islands, Daisy explained that students are not actually required to have a pass grade in English to get a job. In fact, languages such as Chinese, German, and French are more commonly spoken at this tourist destination. Students, according to Daisy, were less motivated to learn English for this reason, which, in turn, was one of the main drivers for Daisy to move away from the given tools to find other approaches to keep her students engaged.

...most of the students don't like to learn English. Not only English but other subjects too. Because once they have completed grade 10, they will get a job. They do not need to get passing marks. If they sat in the exam, they will get a job... maybe from the resort, or from the airport or somewhere else. Because of this, they are not paying interest in studying. They (just) have to attend school until they finish grade 10.

However, Edmon faced a different situation. In the rural island where Edmon taught, the principal reported that there were no job opportunities available on the island and the nearby islands. According to Edmon and other teachers in the school, there were no resorts around the island and neither was it a fishing area. The only career opportunities for the students were the few jobs available in the public sector, such as the health centre, schools and the island council: "Many people have gone to (the) other islands. The good students are gone... to get (a) better education, and 
better health facilities. We have very few students and they are weak in English," Edmon explained. According to Edmon, the students who remained on the island were mostly weak academically and seemed to lack motivation to learn. This created a huge challenge for Edmon when implementing the curriculum. According to Edmon, he had to make his own materials in response to this situation.

Other contextual features such as the professional guidance available to teachers, as well as the extent of parental involvement, were said to shape the way teachers used the curriculum. For example, in the urban school, the teachers were monitored more closely. The teachers at the urban school received instructional coaching from qualified leading teachers to support their curriculum implementation. In the rural schools, there was significantly less support and guidance, especially by one who has appropriate pedagogical content expertise as leading teachers were not specialised in teaching English.

In the urban school, parents were more educated and had higher expectations regarding their children's educational opportunities. Becky and Ashia stated that parents often expressed their concerns regarding the students' learning in the class Viber (an instant messaging app) group and at parent meetings. Becky reported: "For example, yesterday I gave a rough idea about a leaflet project which will be assessed. I got messages from parents in the Viber group about it and (as a result) I had to conduct a group activity before giving the assessed project." Parents in the rural islands tended to be less involved, and perhaps also more limited by a lack of resources: "The curriculum is very much ICT-based. So, if students do not get this opportunity at home, it is very difficult to implement and achieve the key competencies," Faiha said.

\section{Omission}

The analysis of the data identified that all the teachers at some point omitted the tool either while planning for lessons or during implementation of lessons. They skipped the tool or replaced it with more suitable material or tasks depending upon the students' interest or level of competency. For example, it was identified that all the teachers omitted the activity on poems that was given in the textbook for different reasons. This is because teachers, particularly those in the urban area felt that it was not useful for the students' learning while those in the rural area found that poems were too difficult for their students to understand.

\section{Discussion and Implications}

Similar to many other studies (see, for example, Ball \& Cohen, 1996; Brown, 2009; Remillard, 2005), this research has found that a multi-layered and complex relationship exists between the teacher and the curriculum tools. The study has also lent support to the idea that the relationship between the teacher and the curriculum is dynamic and is bidirectional. The teacher-tool relationship varies at different stages of the instruction, particularly in a task-based teaching subject like English; and it can vary from one activity to another and from one lesson to another. In this study, however, a multilateral relationship becomes more explicit: the teacher, the context and the tool act upon each other to shape the classroom instruction. In other words, the particular features of each of the three elements may constrain or afford the curriculum implementation process in real classroom settings. Similar to the tool and the teacher, the characteristics of the context may present limitations and possibilities which could influence how teachers interact and use the curriculum.

It is important to note that even though Brown (2009) and Remillard (2005) have highlighted that contextual features within and beyond the education system can have an important influence on how teachers use the curriculum, they did not identify specific features of the context that could shape teacher-tool relationship. Other researchers have identified context-related features such as time constraints (Bodzin et al., 2003), teaching resources (Nargund-Joshi et al., 2011), and peer coaching (Roehrig et al., 2007), but these are features already embedded within the education system. 
This study, in contrast, has identified and described how a unique socioeconomic, geographical and cultural context can significantly shape the teacher-tool relationship. In other words, the context (i.e. parents' involvement, students' learning experiences; school goals, job opportunities; professional guidance) also plays a significant role in mediating the interaction between the teacher and artefact. The interaction between the teacher and the tools is also shaped by the context in which this relationship is situated.

A modified DCEF framework is, therefore, proposed (See Figure 3). In this framework, the context plays a significant role in influencing the already dynamic teacher-tool relationship. In addition, the goals and beliefs from the original framework are expanded into more specific teacher characteristics: the teacher's experience, the teacher's belief about (language) teaching, and the teacher's attitude towards curriculum. These characteristics seemed to play a significant role in shaping teacher relationships with the tools, ultimately changing their behaviour in the classroom. Similar to a number of other studies (see, for example, Farrell, 1999; Sato \& Kleinsasser, 1999) that have highlighted the impact of teachers' educational histories on the formation of their beliefs, this study has also identified that teachers' beliefs about language teaching are similar to the instructional approaches that were prominent during their initial experiences of teaching. It was identified that a teacher's curriculum use reflected the teacher's basic belief about language teaching. For example, teachers who believed vocabulary and grammar teaching were an important part of teaching English appeared to be much more likely to adapt tools to include the activities of grammar and vocabulary. However, those teachers who had not experienced explicit teaching of grammar and vocabulary in their schools and teacher training did not teach them explicitly. This is because their belief about these aspects of language was different.

\section{Figure 3: The Proposed Extension of DCE Framework}

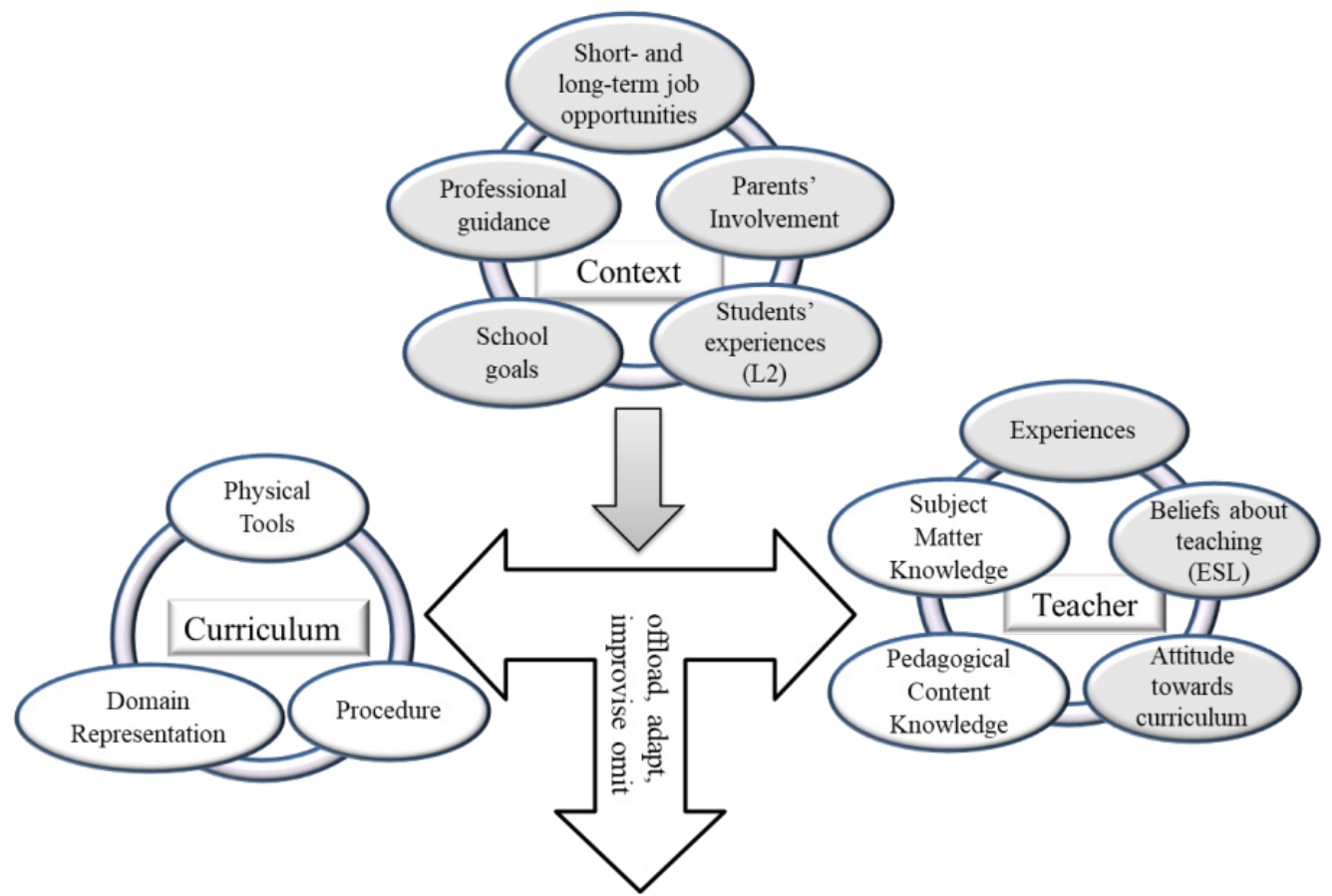

Instructional Outcomes 
The national vision for the new curriculum of Maldives is expressed as "Every child is prepared for life" (National Institute of Education (NIE), 2013). Hence, teachers are encouraged to help develop the individual skills of each child to prepare them for the future. However, there must be greater recognition that distinct contextual features as shaped by a unique set of social, economic and geographic circumstances can give rise to distinct socio-economic systems, which in turn may have a powerful impact on the teacher-tool relationship. Therefore, it is important to recognize that curriculum as well as teacher education should be designed in a way that accounts for these situation-based dynamics. For instance, curriculum and assessment structures need to be designed in a way that empowers teachers in the more rural settings to adapt and improvise the curriculum to better accommodate the needs of students and parents. Even though it is easy to implement and standardize one curriculum that fits all, the reality is that no curriculum can fit all students' needs in a community distributed across a large number of islands. On the other hand, teacher education should prepare teachers who are more capable to improvise and adapt the curriculum to suit the learning needs of students living in different socio-economic contexts (Wang \& Hsieh. 2017; Yazdi, 2013).

\section{References}

Aturupane, H., \& Shojo, M. (2012). Enhancing the Quality of Education in the Maldives: challenges and prospects (South Asia Human Development Sector report no. 51.) Washington, DC: World Bank.

Ball, D. L., \& Cohen, D. K. (1996). Reform by the book: What is-or might be-the role of curriculum materials in teacher learning and instructional reform? Educational Researcher, 25(9), pp.6-8.

Bodzin, A. M., Cates, W. M., \& Price, B. (2003). Formative Evaluation of the Exploring Life Curriculum: Year two implementation fidelity findings. Paper presented at the meeting of the National Association for Research in Science Teaching (NARST), Philadelphia, PA.

Brown, M. (2009). The teacher-tool relationship: Theorizing the design and use of curriculum materials. In J. T. Remillard, B. A. Herbel-Eisenmann, \& G. M. Lloyd (Eds.), Mathematics Teachers at Work: Connecting Curriculum Materials and Classroom Instruction. New York: Routledge, pp.17-36.

Brown, M., \& Edelson, D. C. (2003). Teaching as Design: Can we better understand the ways in which teachers use materials so we can better design materials to support their changes in practice? Evanston, IL: LETUS.

Collopy, R. (2003). Curriculum materials as a professional development tool: How a mathematics textbook affected two teachers' learning. Elementary School Journal, 103(3), pp. 287-311.

Crossley, M. (2010). Context matters in educational research and international development: Learning from the small states experience. Prospects, 40(4), pp.421-429.

Di Biase, R. (2015). Learning from a small state's experience: Acknowledging the importance of context in implementing learner-centred pedagogy. The International Education Journal: Comparative Perspectives, 14(1), pp. 1-20.

Farrell, T. S. C. (1999). The reflective assignment: Unlocking pre-service teachers 'beliefs on grammar teaching. RELC Journal, 30(2), pp.1-17.

Freeman, D. J., \& Porter, A. C. (1989). Do textbooks dictate the content of mathematics instruction in elementary schools? American Educational Research Journal, 26(3), pp.403-421.

Jacobs, J. K., Kawanaka, T., \& Stigler, J. (1999). Integrating qualitative and quantitative approaches to the analysis of video data on classroom teaching. International Journal of Educational Research, 31(8), pp. 717-724.

Lisle, J. D. (2012). Explaining whole system reform in small states: The case of the Trinidad and Tobago secondary education modernisation. Current Issues in Comparative Education, 15(1), pp. 64-82.

Lloyd, G. M. (2008). Curriculum use while learning to teach: One student teacher's appropriation of mathematics curriculum materials Journal for Research in Mathematics Education, 39(1), pp. 63-94. 
McLaughlin, M. W. (1978). Implementation as mutual adaptation. Teachers College Record, 77, pp. 339-351.

Merriam, S. B. (1998). Qualitative Research and Case Study Applications in Education. San Francisco, CA: Jossey-Bass Publishers.

Merriam, S. B. (2009). Qualitative Research: A guide to design and implementation.. San Francisco, CA: Jossey-Ba

Nargund-Joshi, V., Rogers, M. A. P., \& Akerson, V. L. (2011). Exploring Indian secondary teachers' orientations and practice for teaching science in an era of reform. Journal of Research in Science Teaching, 48(6), pp.624-647.

National Bureau of Statistics (NBS). (2015) Statistical Pocket Book of Maldives. Available at: gov.mv/ nbs/wp-content/.../10/Statistical-Pocketbook-of-Maldives2015.pdf [Accessed 20 September 2016].

National Institute of Education (NIE). (2013). The National Curriculum Framework. Available at: https://www.moe.gov.mv/assets/upload/National_Curriculum_Framework_English.pdf. [Accessed 5 March 2016].

Remillard, J. T. (2005). Examining key concepts in research on teachers' use of Mathematics curricula. Review of Educational Research, 75(2), pp. 211-246.

Remillard, J. T., \& Bryans, M. B. (2004). Teachers' Orientations toward Mathematics curriculum materials: Implications for teacher learning. Journal for Research in Mathematics Education, 35(5), pp. 352-388.

Roehrig, G. H., Kruse, R. A., \& Kern, A. (2007). Teacher and school characteristics and their influence on curriculum implementation. Journal of Research in Science Teaching. 44(7), pp.883-907.

Sato, K., \& Kleinsasser, R. C. (1999). Communicative Language Teaching (CLT): Practical understandings. The Modern Language Journal, 83(4), pp. 494-517.

Sherin, M G., \& Drake, C. (2009). Curriculum strategy framework: investigating patterns in teachers' use of a reform-based elementary mathematics curriculum. Journal of Curriculum Studies, 41(4), pp. 467-500.

Shiuna, M., \& Sodiq, A. (2013). Improving education in the Maldives: Stakeholder perspectives on the Maldivian education. International Journal of Small Economies, 4(1), pp.23-38.

Smith, M. S. (2000). Balancing old and new: An experienced middle school teacher's learning in the context of mathematics instructional reform. Elementary School Journal, 100(4), pp. 351-375.

Snyder, J., Bolin, F., \& Zumwalt, K. (1992). Curriculum implementation. In P. W. Jackson (Ed.), Handbook of Research on Curriculum. New York: Macmillan, pp. 402-435.

Sosniak, L. A., \& Stodolsky, S. S. (1993). Teachers and textbooks: Materials use in four fourth-grade classrooms. Elementary School Journal, 93(3), pp.249-275.

Tee, M. Y., Samuel, M., Nor, N. B. M., \& Nadarajan, S. (2016). A methodological approach for researching national classroom practices. Journal of International and Comparative Education (JICE), 5(1), pp. 1-17.

Vygotsky, L. S. (1978). Mind in Society. Cambridge, MA: Harvard University Press.

Wang, T. C., \& Hsieh, H.C., (2017). An analysis of school-based curriculum development; The Taiwanese School of Melbourne. International Journal of Business and General Management, (6)1, pp.17-24.

Wertsch, J. V. (1991). Voices of the Mind: A sociocultural approach to mediated action. Cambridge, MA: Harvard University Press.

Yan, C. (2012). 'We can only change in a small way': A study of secondary English teachers' implementation of curriculum reform in China. Journal of Educational Change, 13(4), pp. 431-447.

Yazdi, S.V. (2013). Review of centralization and decentralization; Approaches to curriculum development in Iran. International Journal of Academic Research in Business and Social Science, 3(4), pp.97-115. 
